Hamilton, K.O., Yazdanian, M., and Audus, K.L. (2001) Modulation of P-glycoprotein activity in Calu-3 cells using steroids and bligands. Int. J. Pharm. 228, 171-179. PMID: 11576779. Publisher's official version: <http://dx.doi.org/10.1016/S0378-

5173(01)00836-5> . Open Access version: http://kuscholarworks.ku.edu/dspace/.

[This document contains the author's accepted manuscript. For the publisher's version, see the link in the header of this document.]

Paper citation: Hamilton, K.O., Yazdanian, M., and Audus, K.L. (2001) Modulation of P-glycoprotein activity in Calu-3 cells using steroids and b-ligands. Int. J. Pharm. 228, 171-179. PMID: 11576779

Keywords: Calu-3, P-glycoprotein, modulation, steroids, $\beta$-ligands

Abstract: The purpose of this work was to investigate if P-glycoprotein (Pgp) efflux pump activity could be inhibited in the sub-bronchial epithelial cell line, Calu-3, by glucocorticosteroids and $\beta$ ligands. The Pgp modulation efficiency of each compound was determined by its ability to increase the accumulation of the Pgp substrate rhodamine 123 (Rh123) accumulation in these cells. Pgp inhibition was observed at $\geq 100 \mu \mathrm{M}$ steroids and $\beta$-ligand. The modulation effectiveness of the $\beta$-ligands increased with increasing hydrophobicity (log $P_{\text {octanol/aqueous }}$ ) whereas an obvious correlation was not obtained with the complete set of steroids tested. Steroidal Pgp substrates did not affect Rh123 accumulation (e.g., aldosterone, dexamethasone, $11 \beta, 17 \alpha, 21-\mathrm{OH}$ progesterone). In contrast, two hydrophobic non P-gp steroidal substrates (testosterone and progesterone) displayed different effects on Rh123 accumulation, with progesterone being the more potent modulator. The most hydrophobic $\beta$-ligand, propranolol, a known Pgp substrate, gave the largest increase in Rh123 accumulation in this therapeutic class. The $\beta$-ligand modulation efficiency could also be correlated to Pgp structural recognition elements such as hydrogen bonding potential, the presence of a basic nitrogen and planar aromatic ring. No effect on Rh123 accumulation was observed with the formulation additives tested (ethanol, glycerol and palmitoyl carnitine) at concentrations previously reported to be non-toxic to Calu-3 cells.

Text of paper: 
Hamilton, K.O., Yazdanian, M., and Audus, K.L. (2001) Modulation of P-glycoprotein activity in Calu-3 cells using steroids and bligands. Int. J. Pharm. 228, 171-179. PMID: 11576779. Publisher's official version: <http://dx.doi.org/10.1016/S03785173(01)00836-5>. Open Access version: http://kuscholarworks.ku.edu/dspace/.

\section{Modulation of P-glycoprotein activity in Calu-3 cells using steroids and $\beta$-ligands}

Karen O. Hamiltona, Mehran A. Yazdanian ${ }^{b}$ and Kenneth L. Audus ${ }^{*}$

${ }^{a}$ Department of Pharmaceutical Chemistry, The University of Kansas, Simons Laboratories, 2095

Constant Avenue, Lawrence, KS 66047-3729

${ }^{\mathrm{b}}$ Department of Pharmaceutics, Boehringer Ingelheim Pharmaceutics, Inc., 900 Ridgebury Rd, Ridgefield, CT, 06877

*Corresponding author

Dr. Kenneth L. Audus

Tel : 7858643609

Fax: 7858645736

E-mail: audus@ku.edu 
Hamilton, K.O., Yazdanian, M., and Audus, K.L. (2001) Modulation of P-glycoprotein activity in Calu-3 cells using steroids and bligands. Int. J. Pharm. 228, 171-179. PMID: 11576779. Publisher's official version: <http://dx.doi.org/10.1016/S0378-

5173(01)00836-5> . Open Access version: http://kuscholarworks.ku.edu/dspace/.

\section{INTRODUCTION}

Inhaled glucocorticosteroids are used in asthma therapy for their anti-inflammatory effects (Smith and Bernstein, 1996). A number of studies have shown that glucocorticosteroids interact with Pgp to either bind to, be transported by, or affect the expression and action of this efflux pump. The high levels and wide tissue distribution of Pgp expression in the adrenal gland, the site of glucocorticosteroid synthesis, provided an early indication that Pgp may play a role in steroid transport (Fojo et al., 1987; Thiebaut et al., 1987). Consistent with these observations, it was later shown that Pgp transports aldosterone, cortisol and dexamethasone, however the more hydrophobic steroids, $\beta$-estradiol, progesterone and testosterone are not substrates for Pgp efflux (Ueda et al., 1992; Ueda et al., 1994). The incorporation of hydroxyl groups on the steroid ring system at carbons 11, 16, 17 and 21, impart varying degrees of decreased hydrophobicity, and has been shown to determine steroid transport by Pgp (Gruol et al., 1994). A relationship between increased steroid hydrophobicity and increased retention of the Pgp substrate vinblastine has also been demonstrated (Yang et al., 1989). In similar studies, Naito et al. (1989) reported inhibition of binding of another Pgp substrate, vincristine, by several steroid hormones including $\beta$-estradiol, cortisone, corticosterone, testosterone and progesterone. Finally, steroids have also been shown to regulate Pgp expression. Estrogen and progesterone have been reported to induce murine $m d r 1$ and Pgp expression in the uterus during pregnancy (Arceci et al., 1990). On the other hand, dexamethasone modulation of Pgp expression appears to be tissue specific (Sérée et al., 1998; Demeule et al., 1999).

In contrast, there are few reports in the literature on the interactions of $\beta$-ligands with Pgp. The cardioselective $\beta$-blockers acebutolol, celiprolol and talinolol, have been shown to exhibit Pgp-mediated secretion in intestinal Caco-2 cells (Karlsson et al., 1993; Terao et al., 1996; Hilgendorf et al., 2000). Propranolol uptake was reported to be increased by several Pgp ligands including cyclosporin A, progesterone and Rh123, in conjuctival epithelium (Yang et al., 2000). More recently, Pgp was shown to restrict the transport of bunitrolol across the blood-brain barrier (Matsuzaki et al., 1999). Inhaled $\beta_{2^{-}}$ adrenergic agonists such as albuterol and terbutaline provide quick bronchodilatory relief in asthma patients (Smith and Bernstein, 1996). There are no reports, however, on the involvement of Pgp in the pulmonary absorption of anti-asthmatic agents.

The lung is known to express low levels of Pgp relative to other tissues (Fojo et al., 1987). In particular, Pgp expression has been demonstrated in normal human bronchial epithelium and expression levels in normal lung have been reported to exceed those in cancerous tissue (Pavelic et al., 1993; Abe et al., 1994). Although the exact role of Pgp in the lung is unknown, Pgp may function to protect the lung from toxic levels of xenobiotics, as has been proposed for other tissues (Thiebaut et al., 1987). We have recently demonstrated functional Pgp activity in Calu-3 cells, a model of the human sub-bronchial epithelium (Hamilton et al., 2001a). If Pgp does indeed play a role in restricting the absorption of potential substrates in the lung, then circumvention of this pathway may improve the delivery of pulmonary therapeutics. With this is mind, we sought to investigate if Pgp activity in Calu-3 cells could be inhibited with a number of steroids and $\beta$-ligands varying in chemical structure, lipophilicity and their 
Hamilton, K.O., Yazdanian, M., and Audus, K.L. (2001) Modulation of P-glycoprotein activity in Calu-3 cells using steroids and bligands. Int. J. Pharm. 228, 171-179. PMID: 11576779. Publisher's official version: <http://dx.doi.org/10.1016/S03785173(01)00836-5>. Open Access version: http://kuscholarworks.ku.edu/dspace/.

intrinsic ability to be transported by Pgp (Figures 1, 2, 3). Although Rh123 has been shown to be a substrate for both Pgp and MRP1 (Twentyman et al., 1994; Versantvoort et al., 1996), we have shown predominant Pgp activity in Calu-3 cells (Hamilton et al., 2001b) using this marker compound.

\section{MATERIALS AND METHODS}

\subsection{Materials}

Calu-3 cells were obtained from the American Type Culture Collection (Rockville, MD). Cell culture medium and buffer solutions were obtained from Gibco BRL (Gaithersburg, MD). Accumulation studies were all performed in $\mathrm{pH} 7.4$ standard phosphate buffered saline (PBS) supplemented with $0.63 \mathrm{mM}$ $\mathrm{CaCl}_{2}, 0.74 \mathrm{mM} \mathrm{MgSO}_{4}, 5.3 \mathrm{mM}$ glucose and $0.1 \mathrm{mM}$ ascorbic acid (PBSA). Culture flasks $\left(150 \mathrm{~cm}^{2}\right.$ growth area), 12 well cluster dishes $\left(1.1 \mathrm{~cm}^{2}\right.$ growth area) and polycarbonate Transwells $®(0.4 \mu \mathrm{M}$ pore size) were obtained from Corning Costar (Cambridge, MA). Aldosterone, beclomethasone, budenoside, cylcosporine A, dexamethasone, flunisolide, rhodamine 123, testosterone, triamcinolone, progesterone, $11 \alpha-\mathrm{OH}$ progesterone, $11 \beta-\mathrm{OH}$ progesterone, $21-\mathrm{OH}$ progesterone, $11 \beta, 11 \beta, 21-\mathrm{OH}$ progesterone, $17 \alpha$, 21-OH progesterone and $11 \beta, 17 \alpha, 21-\mathrm{OH}$ progesterone were obtained from Sigma (St. Louis, MO). $17 \alpha-$ $\mathrm{OH}$ progesterone was obtained from ICN Biomedicals (Aurora, $\mathrm{OH}$ ). The $\beta$-ligands acebutolol, albuterol hemisulfate, metoprolol, nadolol, propanolol and timolol were also obtained from Sigma. Albuterol sulfate was a gift from Boehringer Ingelheim Inc. (Ridgefield, CT). All other reagents were from Sigma. Cyclosporin A (CSA) was first dissolved in methanol (Fisher Scientific, Fair Lawn, NJ) to $5 \mathrm{mM}$ then aliquots diluted in PBS to give a $5 \mu \mathrm{M}$ final working concentration.

\subsection{Cell culture}

All cell lines were maintained in a $95 \%$ humidified $/ 10 \% \mathrm{CO}_{2}$ atmosphere at $37^{\circ} \mathrm{C}$. Calu- 3 cells were used between passages 19 and 40 . The cells were grown in $150 \mathrm{~cm}^{2}$ flasks and maintained in a 1:1 mixture of Ham's F12:DMEM containing 10\% fetal bovine serum (FBS), $100 \mu \mathrm{g} / \mathrm{ml}$ penicillin G and $100 \mu \mathrm{g} / \mathrm{ml}$ streptomycin sulfate. When the cells reached 90\% confluency (approximately 4-5 days) they were subcultured at a $1: 2$ split ratio using $0.25 \%$ trypsin/0.1\% EDTA. Caco-2 cells were cultured in DMEM containing 10\% FBS, 1\% non-essential amino acids, $2 \mathrm{mM}$ glutamine, $100 \mu \mathrm{g} / \mathrm{ml}$ penicillin $\mathrm{G}$ and 100 $\mu \mathrm{g} / \mathrm{ml}$ streptomycin sulfate. A549 cells were maintained in Ham's F-12 medium supplemented with $10 \%$ FBS, $100 \mu \mathrm{g} / \mathrm{ml}$ penicillin $\mathrm{G}$ and $100 \mu \mathrm{g} / \mathrm{ml}$ streptomycin sulfate.

\subsection{Rh123 accumulation assay}


Hamilton, K.O., Yazdanian, M., and Audus, K.L. (2001) Modulation of P-glycoprotein activity in Calu-3 cells using steroids and bligands. Int. J. Pharm. 228, 171-179. PMID: 11576779. Publisher's official version: <http://dx.doi.org/10.1016/S0378-

5173(01)00836-5> . Open Access version: http://kuscholarworks.ku.edu/dspace/.

Cells were seeded onto 12 well cluster dishes at a density of $5 \times 10^{5}$ cells $/ \mathrm{cm}^{2}(1 \mathrm{ml}$ per well). The culture medium was changed every other day after seeding until a confluent monolayer was formed (by day 4) as determined by light microscopy. Experiments were performed in PBSA. All experiments were performed with gentle agitation $(\sim 30 \mathrm{rpm})$ at $37^{\circ} \mathrm{C}$. The growth medium was first aspirated off and then the cells were rinsed three times with pre-warmed $\left(37^{\circ} \mathrm{C}\right)$ PBSA. The monolayers were then equilibrated either in $1 \mathrm{ml} \mathrm{PBSA}$ for 1 hour at $37^{\circ} \mathrm{C}$ for control experiments or equilibrated for 30 minutes in PBSA alone, followed by another 30 minute pre-incubation with the steroid, $\beta$-ligand or excipient. CsA $(5 \mu \mathrm{M})$ was used as the positive control. Rh123 accumulation was then performed for 2 hours with or without modulator present. At the end of the experiment, the drug solution was removed by aspiration and the monolayers were immediately rinsed three times with ice-cold PBSA. Each monolayer was solubilized for 30 minutes $\left(37^{\circ} \mathrm{C}\right)$ with $1 \mathrm{ml}$ of lysing solution $(0.5 \% \mathrm{v} / \mathrm{v}$ Triton X-100 in $0.2 \mathrm{~N}$ $\mathrm{NaOH})$. For cells grown in 96 well format $\left(0.32 \mathrm{~cm}^{2}\right.$ total surface area), the following adjustments were made to the protocol outlined above. Cells were plated at the same density with $100 \mu \mathrm{l}$ per well, and a confluent monolayer was formed by day 2 . Volumes for preincubations and incubations were $100 \mu \mathrm{l}$ and cells were lysed in $200 \mu \mathrm{l}$ volume. For both plating conditions, cell lysates were assayed using a microplate fluorescence reader (Bio-Tek Instruments, Winooski, VT) at excitation/emission wavelengths of $485 \mathrm{~nm} / 520 \mathrm{~nm}$, then quantified against standard curves of Rh123 in lysing solution. The fluorescence of the cell lysates was corrected for autofluorescence of untreated cells. The protein content of each monolayer was then determined using the BCA protein assay reagent kit. Results were 
Hamilton, K.O., Yazdanian, M., and Audus, K.L. (2001) Modulation of P-glycoprotein activity in Calu-3 cells using steroids and bligands. Int. J. Pharm. 228, 171-179. PMID: 11576779. Publisher's official version: <http://dx.doi.org/10.1016/S03785173(01)00836-5>. Open Access version: http://kuscholarworks.ku.edu/dspace/.

expressed as total Rh123 accumulation per $\mu$ g cellular protein or a percentage of Rh123 uptake compared to control wells.

\subsection{Software analysis}

All experiments were performed at least in quadruplicate. Data are presented as mean \pm standard deviation. Statistical significance and linear regression analyses were performed using the unpaired student's t-test (Sigma Plot ${ }^{\circledR}$ version 4.01) determined at the $95 \%$ confidence level. Estimated log P values (log Kow) were retrieved from the online-interactive Syracuse Research Corporation KowWin program (http://esc.syrres.com/interkow/kowdemo.htm).

\section{RESULTS}

\subsection{Effect of progesterone, dexamethasone and their analogs}

For most agents tested, an increase in Rh123 accumulation was not observed until $100 \mu \mathrm{M}$ concentration. Figure 4 shows the correlation between estimated log P (log Kow) and \% Rh123 of control values. Log Kow values were plotted rather than log $\mathrm{P}$ values due to incomplete availability of measured log $\mathrm{P}$ values in the literature. It should be noted that the overall data trend was not affected by plotting log Kow rather than log P. Modulation efficiency appears to fall into three distinct categories, relative to log Kow; log Kow of 3.67, log Kow between 3.08 and 3.27 and log Kow less than 2.18. No modulation was observed with steroids that are highly transported by Pgp (aldosterone, dexamethasone, $11 \beta, 17 \alpha, 21-\mathrm{OH}$ progesterone). On the other hand, testosterone and progesterone, compounds that do not display Pgp transporting activity, increased Rh123 accumulation approximately 1.7 and 4.0 fold, respectively. Progesterone analogs with varying degrees of hydroxyl substitution showed varying degrees of modulation. The inhalation steroids also varied in their Pgp inhibitory effects, with triamcinolone being the least effective of this series. A summary of all the steroids tested along with their corresponding log $\mathrm{P}$ and $\log$ Kow values relative to modulation efficiency is shown in Table 1.

\subsection{Effect of $\beta$-ligands}

A concentration dependent effect was also observed ( $1 \mu \mathrm{M}$ to $1 \mathrm{mM}$ ) for all the compounds tested, with higher concentrations showing greater inhibitory effects on Rh123 efflux. Representative dose response curves are shown in Figure 5 for the $\beta$-ligands nadolol and metoprolol. Figure 6 shows the correlation between log P and Rh123 accumulation (as \% control) for the seven $\beta$-ligands tested (100 $\mu \mathrm{M})$. The data for the $100 \mu \mathrm{M}$ treatment are summarized in Table 2 using a ranking system similar to that provided for the steroids in Table 1. A clear trend was observed between increasing log $P$ and the ability to inhibit Rh123 efflux. However, the Pgp substrate propranolol gave the largest increase in 
Hamilton, K.O., Yazdanian, M., and Audus, K.L. (2001) Modulation of P-glycoprotein activity in Calu-3 cells using steroids and bligands. Int. J. Pharm. 228, 171-179. PMID: 11576779. Publisher's official version: <http://dx.doi.org/10.1016/S0378-

5173(01)00836-5>. Open Access version: http://kuscholarworks.ku.edu/dspace/.

Rh123 accumulation. Cellular toxicity was observed with this agent at $>100 \mu \mathrm{M}$, which was manifested as a decrease in Rh123 and detachment of the cell monolayer from the plastic support during the incubation period. Metoprolol, acebutolol and timolol showed similar inhibitory effects relative to each other. No modulation was observed with those compounds exhibiting log P values $<1$. No effect on Rh123 accumulation was observed with the bronchodilator, albuterol.

\subsection{Effect of ethanol, glycerol and palmitoyl carnitine}

The effects of various formulation additives on Pgp activity were investigated (data not shown). No effect on Rh123 accumulation was observed with $0.1 \%(\mathrm{v} / \mathrm{v})$ and $1.0 \%(\mathrm{v} / \mathrm{v})$ glycerol. Similarly, $0.05 \%$ $(\mathrm{v} / \mathrm{v})$ and $0.5 \%(\mathrm{v} / \mathrm{v})$ DMSO; $0.08 \% \mathrm{EtOH} ; 0.08 \%(\mathrm{v} / \mathrm{v})$ and $0.82 \% \mathrm{MeOH}$ solvent controls did not affect Rh123 accumulation. The permeation enhancer palmitoyl carnitine did not affect Rh123 accumulation at $10 \mu \mathrm{M}$. The $100 \mu \mathrm{M}$ treatment, however, also resulted in cellular toxicity similar to those observed with high concentrations of propranolol.

\section{DISCUSSION}

We show here that steroids and $\beta$-ligands vary in their ability to modulate Pgp in Calu-3 cells. Whereas both therapeutic classes inhibit Rh123 efflux with increasing hydrophobicity, steroidal Pgp substrates are non-modulating while the $\beta$-ligand substrate, propranolol was the most effective inhibitor in its class. Although propranolol and progesterone exhibit similar log $\mathrm{P}$ values (3.21 and 3.26, respectively), progesterone increased Rh123 accumulation 4-fold, while propranolol produced a 2 -fold increase in accumulation. Thus, progesterone appears to be a more potent inhibitor of Pgp efflux at equimolar concentrations using the model substrate, Rh123.

Certain structural elements have previously been identified as essential for recognition by Pgp. These include a basic nitrogen atom, and the presence of at least one planar aromatic ring (Pearce et al., 1989). The $\beta$-ligands tested are all weak bases, and therefore positively charged at physiological $\mathrm{pH}(\mathrm{pKa} \approx 9.5)$. This additional feature would make these compounds ideal 
Hamilton, K.O., Yazdanian, M., and Audus, K.L. (2001) Modulation of P-glycoprotein activity in Calu-3 cells using steroids and bligands. Int. J. Pharm. 228, 171-179. PMID: 11576779. Publisher's official version: <http://dx.doi.org/10.1016/S0378-

5173(01)00836-5> . Open Access version: http://kuscholarworks.ku.edu/dspace/.

candidates for interaction with Pgp. It has also been suggested that substrate binding to Pgp is approximately proportional to the number and strength of hydrogen bonds formed between the Pgp ligand and receptor protein (Seelig, 1998). Furthermore, it has been shown that carbonyl groups and ether linkages are prevalent in Pgp substrates (Seelig, 1998). Propranolol possesses an ether linkage coupled to a fused aromatic ring system. This unique structural combination is absent in any of the other $\beta$-ligands tested, and may account for the enhanced inhibitory effect of this compound.

On the other hand, the steroids tested represent un-ionizable compounds, and lack a basic nitrogen atom, in addition to aromaticity. Their ability to be recognized by Pgp therefore may be a function of relative hydrophobicity, rather than the structural requirements outlined above (Ueda et al., 1997). The ability of these steroids to modulate Pgp also appears to follow the same pattern observed for substrate recognition. The highly transported Pgp substrates aldosterone, dexamethasone and the tri-hydroxyl substituted progesterone analog, did not modulate Rh123 efflux. The moderately transported progesterone analogs (mono- and dihydroxyl substituted) gave intermediate effects, increasing Rh123 accumulation 1.4 to 2.1 fold. Interestingly, the non-transported steroid progesterone was a greater inhibitor of Rh123 efflux than CsA (\% Rh123 control $=307.1 \pm 18.4,5 \mu \mathrm{M}$ CsA; $405.0 \pm 38.5,100 \mu \mathrm{M}$ progesterone) Testosterone differs from progesterone by possessing a hydroxyl group on the position-20 carbon, however, this steroid did affect Pgp activity (1.7-fold). Thus, hydroxylation at carbon 20 may be important for steroidal modulation of this efflux pump transporter. 
Hamilton, K.O., Yazdanian, M., and Audus, K.L. (2001) Modulation of P-glycoprotein activity in Calu-3 cells using steroids and bligands. Int. J. Pharm. 228, 171-179. PMID: 11576779. Publisher's official version: <http://dx.doi.org/10.1016/S0378-

5173(01)00836-5> . Open Access version: http://kuscholarworks.ku.edu/dspace/.

Of the inhalation steroids tested, budenoside was the most potent modulator, second only to CSA in Pgp inhibitory effect. The closely related steroid, flunisolide, displayed intermediate effects on Pgp activity. These differences can most likely be attributed to chemical structure

(Figure 2). The only other fluorinated steroid tested was triamcinolone, for which no modulation of Pgp activity was observed despite possessing two hydroxyl groups on carbons 16 and 17.

Finally, we investigated the ability of various formulation additives to affect Pgp activity. Foster et al. (2001) reported that a concentration of glycerol of up to $1 \%(\mathrm{v} / \mathrm{v})$ did not affect ion movement across Calu-3 monolayers as assessed by measurement of transepithelial electrical resistance (TEER) values. We did not observe any changes in Rh123 accumulation at $0.1 \%$ and $1 \%(\mathrm{v} / \mathrm{v})$ of this cosolvent. DMSO, ethanol and methanol were tested in the studies reported here at the given concentrations as vehicle controls; none of these agents caused an apparent effect on Pgp activity. The permeation enhancer, palmitoyl carnitine did, however, prove to be cytotoxic at $100 \mu \mathrm{M}$. This result is consistent with previous studies reporting tissue irritancy of this formulation agent.

\section{CONCLUSIONS}

We have shown that steroids and $\beta$-ligands can be used to modulate Pgp activity in vitro, however, both classes of agents display unique physico-chemical and structural features that may explain the differences observed in modulation efficiency. It should be noted, however, that a more detailed structure activity relationship would be needed to confirm the data and 
Hamilton, K.O., Yazdanian, M., and Audus, K.L. (2001) Modulation of P-glycoprotein activity in Calu-3 cells using steroids and bligands. Int. J. Pharm. 228, 171-179. PMID: 11576779. Publisher's official version: <http://dx.doi.org/10.1016/S0378-

5173(01)00836-5> . Open Access version: http://kuscholarworks.ku.edu/dspace/.

hypotheses presented here. Of the 100 compounds initially detailed by Seelig et al. (1998) for Pgp substrate activity, the only bronchodilator listed was epinephrine, which was reported not to be a substrate for the efflux pump transporter. It may well be that due to the low levels of Pgp found within the lung, the necessity for circumvention of this transporter is unwarranted.

The physiological relevance of the relatively high concentrations of compound needed to produce an inhibition of Pgp-mediated efflux needs to be explored further.

\section{ACKNOWLEDGEMENTS}

Financial support for this work was kindly provided for by Boehringer Ingelheim Pharmaceuticals, Inc. 
Hamilton, K.O., Yazdanian, M., and Audus, K.L. (2001) Modulation of P-glycoprotein activity in Calu-3 cells using steroids and bligands. Int. J. Pharm. 228, 171-179. PMID: 11576779. Publisher's official version: <http://dx.doi.org/10.1016/S0378-

5173(01)00836-5> . Open Access version: http://kuscholarworks.ku.edu/dspace/.

\section{REFERENCES}

Abe, Y., Nakamura, M., Ota, E., Ozeki, Y., Tamai, S., Inoue, H., Ueyama, Y., Ogata, T., Tamaoki, N., 1994. Expression of the multidrug resistant gene (mdr1) in non-small cell lung cancer. Jpn. J. Cancer Res., 85, 536-541.

Arceci, R.J., Baas, F., Raponi, R., Horwitz, S.B., Housman, D., Croop, J.M., 1990. Multidrug resistance gene expression is controlled by steroid hormones in the secretory epithelium of the uterus. Mol. Reprod.

Dev., 25, 101-109.

Demeule, M., Jodoin, J., Beaulieu, E., Brossard, M., Béliveau, R., 1999. Dexamethasone modulation of multidrug transporters in normal tissues. FEBS Lett., 442, 208-214.

Fojo, A.T., Ueda, K., Slamon, D.J., Poplack, D.G., Gottesman, M.M., Pastan, I., 1987. Expression of a multidrug-resistance gene in human tumors and tissues. Proc. Natl. Acad. Sci. USA, 84, 265-269.

Foster, K.A., Yazdanian, M.A., Audus, K.L., 2001. Determination of the effect of cosolvents and drugs on Calu-3 monolayer transepithelial electrical resistance (TEER) and metabolic properties. Submitted to J. Pharm. Sci.

Gruol, D.J. and Bourgeois, S., 1997. Chemosensitizing steroids: glucocorticoid receptor agonists capable of inhibiting P-glycoprotein function. Cancer Res., 54:720-727.

Gruol, D.J., Bourgeois, S., 1994. Expression of the mdr1 P-glycoprotein gene: a mechanism of escape from glucorticoid-induced apoptosis. Biochem. Cell. Biol., 72, 561-571. 
Hamilton, K.O., Yazdanian, M., and Audus, K.L. (2001) Modulation of P-glycoprotein activity in Calu-3 cells using steroids and bligands. Int. J. Pharm. 228, 171-179. PMID: 11576779. Publisher's official version: <http://dx.doi.org/10.1016/S03785173(01)00836-5> . Open Access version: http://kuscholarworks.ku.edu/dspace/.

Hamilton, K.O., Topp, E., Maksgiansar, I., Siahaan, T., Yazdanian, M.A., Audus, K.L., 2001b. Multidrug resistance-associated protein-1 functional activity in Calu-3 cells. J. Pharmacol. Exp Ther., 298, in print.

Hamilton, K.O., Backström, G., Yazdanian, M.A., Audus, K.L., 2001a. P-glycoprotein efflux pump expression and activity in Calu-3 cells. J. Pharm. Sci., 90, 647-658.

Hilgendorf, C., Spahn-Langguth, H., Regårdh, C.G., Lipka, E., Amidon, G.L., Lagguth, P., 2000. Caco-2 versus Caco-2/HT29-MTX co-cultured cell lines: permeabilities via diffusion, inside- and outside-directed carrier-mediated transport. J. Pharm. Sci., 89, 63-75.

Izquierdo, M.A., Shoemaker, R.H., Flens, M.J., Scheffer, G.L., Wu, L., Prather, T.R., Scheper, R.J., 1996. Overlapping phenotypes of mutlidrug resistance among panels of human cancer-cell lines. Int. J. Cancer 65, 230-237.

Johnson, M.E., Blankschtein, D., Langer, R., 1995. Permeation of steroids through human skin. J. Pharm. Sci., 84, 1144-1146.

Karlsson, J., Kuo, S.-M., Ziemniak, J., Artursson, P., 1993. Transport of celiprolol across human intestinal epithelial (Caco-2) cells: mediation of secretion by multiple transporters including P-glycoprotein. Br. J. Pharmacol., 110, 1009-1016.

Lampidis, T.J., Castello, C., del Giglio, A., Pressman, B.C., Viallet, P., Trevorrow, K.W., Valet, G.K., Tapiero, H., Savaraj, N., 1989. Relevance of the chemical charge of rhodamine dyes to multiple drug resistance. Biochem. Pharmacol., 38, 4267-4271. 
Hamilton, K.O., Yazdanian, M., and Audus, K.L. (2001) Modulation of P-glycoprotein activity in Calu-3 cells using steroids and bligands. Int. J. Pharm. 228, 171-179. PMID: 11576779. Publisher's official version: <http://dx.doi.org/10.1016/S03785173(01)00836-5>. Open Access version: http://kuscholarworks.ku.edu/dspace/.

Leo, A., Hansch, C., Elkins, D., 1991. Partition coefficients and their uses. Chem. Rev., 71, 525616.

Mathias, N.R., Kim, K.-J., Lee, V.H. , 1996. Targeted drug delivery to the respiratory tract: solute permeability of air-interface cultured rabbit tracheal epithelial cell monolayers. J. Drug Targeting, 4, 79-86.

Matzusaki, J., Yamamoto, C., Miyama, T., Takanaga, H., Matsuo, H., Ishizuka, H., Kawahara, Y., Kuwano, M., Naito, M., Tsuruo, T., Sawada, Y., 1999. Contribution of P-glycoprotein to bunitrolol efflux across blood-brain barrier. Biopharm. Drug Dispos., 20, 85-90.

Meylan, W.M., Howard, P.H., 1995. Atom/fragment contribution method for estimating octanol-water partition coefficients. J. Pharm. Sci., 84, 83-92.

Naito, M., Yusa, K., Tsuruo, T., 1989. Steroid hormones inhibit binding of vinca alkaloid to multidrug resistance related P-glycoprotein. Biochem. Biophys. Res. Comm., 158, 1066-1071.

Pavelic, Z.P., Reising, J., Pavelic, L., Kelley, D.J., Stambrook, P.J., Gluckman, J.L., 1993. Detection of Pglycoprotein with four monoclonal antibodies in normal and tumor tissues. Arch. Otolaryngol. Head Neck Surg., 119, 753-757. 
Hamilton, K.O., Yazdanian, M., and Audus, K.L. (2001) Modulation of P-glycoprotein activity in Calu-3 cells using steroids and bligands. Int. J. Pharm. 228, 171-179. PMID: 11576779. Publisher's official version: <http://dx.doi.org/10.1016/S0378-

5173(01)00836-5> . Open Access version: http://kuscholarworks.ku.edu/dspace/.

Pearce, H.L., Safa, A.R., Bach, N.J., Winter, M.A., Cirtain, M.C., Beck, W.T., 1989. Essential features of the P-glycoprotein pharmacophore as defined by a series of reserpine analogs that modulate multidrug resistance. Proc. Natl. Acad. Sci. USA, 86, 5128-2132.

Ponec, M., Kempenaar, J., Shroot, B., Caron, J.-C., 1986. Glucocorticoids: binding affinity and lipophilicity. J. Pharm Sci. 75, 973-975.

Sérée, E, Villar, P.H., Hevér, A., Guigal, N,, Puyoou, F., Charvet, B., Point-Scomma, H., Lechevalier, E., Lacarelle, B., Barra, Y., 1998. Modulation of MDR1 and CYP3A expression by dexamethasone: evidence for an inverse regulation in adrenals. Biochem, Biophys. Res. Comm., 252, 392-395.

Seelig, A., 1998. A general pattern for substrate recognition by P-glycoprotein. Eur. J. Biochem., 251, 252-261.

Seelig, A., Landwojtowicz, E., 2000. Structure-activity relationship of P-glycoprotein substrates and modifiers. Eur. J. Pharm. Sci., 12, 31-40.

Smith, S.J., Bernstein, J.A., 1996. Therapeutic uses of lung aerosols. In Hickey, A. (Ed.), Inhalation Aerosols, Marcel Dekker, Inc., New York, pp 233-269.

Tayar, N.E., Mark, A.E., Vallat, P., Brunne, R.M., Testa, B., van Gunsteren, W.F., 1993. Solvent-dependent conformation and hydrogen-bonding capacity of cyclosporin A: evidence from partition coefficients and molecular dynamics simulations. J. Med. Chem., 36, 3757-3764. 
Hamilton, K.O., Yazdanian, M., and Audus, K.L. (2001) Modulation of P-glycoprotein activity in Calu-3 cells using steroids and bligands. Int. J. Pharm. 228, 171-179. PMID: 11576779. Publisher's official version: <http://dx.doi.org/10.1016/S03785173(01)00836-5>. Open Access version: http://kuscholarworks.ku.edu/dspace/.

Taylor, D.C., Pownall, R., Burke, W., 1984. The absorption of $\beta$-adrenoceptor antagonists in rat in-situ small intestine; the effect of lipophilicity. J. Pharm. Pharmacol., 37, 280-283.

Terao, T., Hisanaga, E., Sai, Y., Tamai, I., Tsuji, A., 1996. Active secretion of drugs from the small intestinal epithelium in rats by P-glycoprotein functioning as an absorption barrier. J. Pharm. Pharmacol., 48, 1083-1089.

Thiebaut, F., Tsuruo, T., Hamada, H., Gottesman, M.M., Pastan, I., Willingham, M.C., 1987. Cellular localization of the multidrug-resistance gene product P-glycoprotein in normal human tissues. Proc. Natl. Acad. Sci. USA, 84, 7735-7738.

Twentyman, P.R., Rhodes, T., Rayner, S., 1994. A comparison of rhodamine 123 accumulation and efflux in cells with P-glycoprotein-mediated and MRP-associated multidrug resistance phenotypes. Eur. J. Cancer, 30, 1360-1369.

Ueda, K., Okamura, N., Hirai, M., Tanigawara, Y., Saeki, T., Kioka, N., Komano, T., Hori, R., 1992. Human P-glycoprotein transports cortisol, aldosterone, and dexamethasone, but not progesterone. J. Biol. Chem., 267, 24248-24252.

Ueda, K., Saeki, T., Hirai, M., Tanigawara, Y., Tanaka, K., Okamura, M., Yasuhara, M., Hori, R., Inui K., Komano, T., 1994. Human P-glycoprotein as a multi-drug transporter analyzed by using a transepithelial transport system. Jpn. J. Physiol., 44, Suppl 2, S67-S71.

Ueda, K., Taguchi, Y., Morishima, M., 1997. How does P-glycoprotein recognize its substrates? Sem. Cancer Biol., 8, 151-159. 
Hamilton, K.O., Yazdanian, M., and Audus, K.L. (2001) Modulation of P-glycoprotein activity in Calu-3 cells using steroids and bligands. Int. J. Pharm. 228, 171-179. PMID: 11576779. Publisher's official version: <http://dx.doi.org/10.1016/S03785173(01)00836-5>. Open Access version: http://kuscholarworks.ku.edu/dspace/.

Versantvoort, C.H.M., Rhodes, T., Twentyman, P.R., 1996. Acceleration of MRP-associated efflux of rhodamine 123 by genistein and related compounds. Br. J. Cancer 74, 1949-1954.

Yang, C.-P., DePinho, S.G., Greenberger, L.M., Arceci, R.J., Horwitz, S.B., 1989. Progesterone interacts with P-glycoprotein in multidrug-resistant cells and in the endometrium of gravid uterus. J. Biol. Chem., $264,782-788$.

Yang, J.J., Kim, K.-J., Lee, V.H., 2000. Role of P-glycoprotein in restricting propranolol transport in cultured rabbit conjuctival epithelial cell layers. Pharm. Res., 17, 533-538. 
Hamilton, K.O., Yazdanian, M., and Audus, K.L. (2001) Modulation of P-glycoprotein activity in Calu-3 cells using steroids and bligands. Int. J. Pharm. 228, 171-179. PMID: 11576779. Publisher's official version: <http://dx.doi.org/10.1016/S0378-

5173(01)00836-5>. Open Access version: http://kuscholarworks.ku.edu/dspace/.

\section{FIGURE LEGENDS}

Figure 1. (a) Structure of progesterone showing the position of 11-, 17- and 21-OH substitution. (b) Relative transport efficiency of progesterone and some of its substituted analogs by Pgp (Gruol and Bourgeois, 1997).

Figure 2. (a) Structure and (b) chemical modification of dexamethasone and inhalation steroids tested. Known Pgp substrates $\left({ }^{*}\right)$ are marked as indicated.

Figure 3. Structure of $\beta$-ligands tested. Known Pgp substrates $\left(^{*}\right)$ and Pgp modulators (ף) are marked as indicated.

Figure 4. Effect of $100 \mu \mathrm{M}$ steroids on Rh123 accumulation ( 2 hours) in Calu-3 cells. Numbers in bold correspond to the ranking system shown in Table 1. A log P or log Kow value for flunisolide (rank \#7) could not be obtained.

Figure 5. Dose - response of nadolol (N) and metoprolol (M) on Rh123 accumulation ( 2 hours) in Calu-3 cells. $\beta$-ligands were studied at $1,10,100,500$ and $1000 \mu \mathrm{M}$, and $5 \mu \mathrm{M}$ CsA was used as the positive control. ( $* p<0.05$ compared to control)

Figure 6. Effect of $100 \mu \mathrm{M} \beta$-ligands on Rh123 accumulation ( 2 hours) in Calu-3 cells. Numbers in bold correspond to the ranking system shown in Table 2.

Table 1. Effect of progesterone, progesterone analogs, dexamethasone and inhalation steroids on Rh123 accumulation in Calu-3 cells. Steroids are shown in decreasing estimated log $\mathrm{P}$ octanol/aqueous (log Kow) values. The ranking system indicates the relative effect of each steroid, with 1 being the most potent, and 16 being the least effective. Available measured $\log \mathrm{P}_{\text {octanol/aqueous }}$ values ( $\left.\log \mathrm{P}\right)$ for $\mathrm{Rh} 123$, CsA and some steroids are indicated for comparison. (n.a. = data not available).

\begin{tabular}{|c|c|c|c|}
\hline Steroid & $\log P$ & log Kow & Rank \# \\
\hline progesterone & $3.26^{\#}$ & 3.67 & 1 \\
\hline testosterone & $3.31 * *$ & 3.27 & 6 \\
\hline $17 \alpha, 21-\mathrm{OH}$ & $2.04^{\#}$ & 3.15 & 9 \\
\hline $21-O H$ & $2.70^{\#}$ & 3.12 & 3 \\
\hline
\end{tabular}


Hamilton, K.O., Yazdanian, M., and Audus, K.L. (2001) Modulation of P-glycoprotein activity in Calu-3 cells using steroids and bligands. Int. J. Pharm. 228, 171-179. PMID: 11576779. Publisher's official version: <http://dx.doi.org/10.1016/S0378-

5173(01)00836-5> . Open Access version: http://kuscholarworks.ku.edu/dspace/.

* Tayar et al. (1993)

\# Ponec et al. (1986)
** Johnson et al. (1995)

"Lampidis et al. (1989) 
Hamilton, K.O., Yazdanian, M., and Audus, K.L. (2001) Modulation of P-glycoprotein activity in Calu-3 cells using steroids and bligands. Int. J. Pharm. 228, 171-179. PMID: 11576779. Publisher's official version: <http://dx.doi.org/10.1016/S0378-

5173(01)00836-5> . Open Access version: http://kuscholarworks.ku.edu/dspace/.

Table 2. Effect of $\beta$-ligands on Rh123 accumulation in Calu-3 cells. $\beta$-ligands are shown in decreasing measured $\log P_{\text {octanol/aqueous }}(\log P)$ values. The ranking system indicates the relative effect of each $\beta$ ligand, with 1 being the most potent, and 7 being the least effective. Log P values and ranking for Rh123 and CsA are included for comparison.

$\begin{array}{lll}\underline{\beta \text {-ligand }} & \underline{\log P} & \underline{\text { Rank\# }} \\ \text { propranolol } & 3.21^{\%} & 1 \\ \text { CsA } & 2.92^{b} & -- \\ \text { timolol } & 1.91^{\wedge} & 3 \\ \text { metoprolol } & 1.88^{@} & 2\end{array}$

*Boehringer Ingelheim, Inc.

\# Leo et al. (1971)

aLampidis et al. (1989)

"Taylor et al. (1985)

^Terao et al. (1996)

@Mathias et al. (1996)

${ }^{\mathrm{b}}$ Tayar et al. (1993)

${ }^{\%}$ Yang et al. (2000). 
Hamilton, K.O., Yazdanian, M., and Audus, K.L. (2001) Modulation of P-glycoprotein activity in Calu-3 cells using steroids and bligands. Int. J. Pharm. 228, 171-179. PMID: 11576779. Publisher's official version: <http://dx.doi.org/10.1016/S03785173(01)00836-5> . Open Access version: http://kuscholarworks.ku.edu/dspace/.

\section{Figure 1.}

(a)

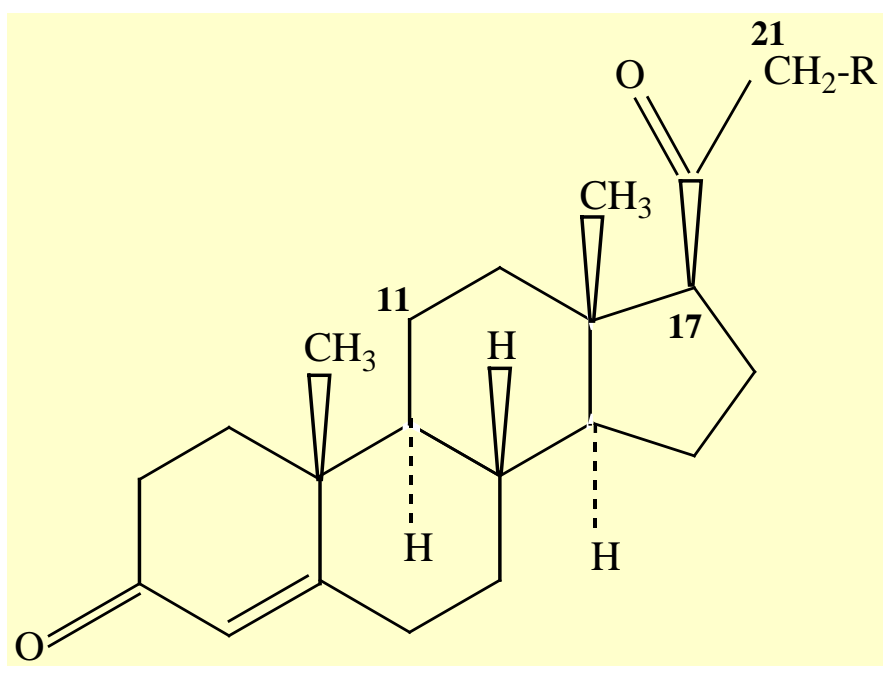

(b)

$\begin{array}{lllll}\text { Steroid } & \underline{11} & \underline{17} & \underline{21} & \text { No Pgp } \\ \text { Progesterone } & \mathrm{H} & \mathrm{H} & \mathrm{H} & \text { traperport } \\ \text { Cortexolone } & \mathrm{H} & \mathrm{OH}(\alpha) & \mathrm{OH} & \\ \text { Coricosterone } & \mathrm{OH}(\beta) & \mathrm{H} & \mathrm{OH} & \\ \text { Cortisol } & \mathrm{OH}(\beta) & \mathrm{OH}(\alpha) & \mathrm{OH} & \text { Efficient Pgp } \\ \ldots & \mathrm{H} & \mathrm{H} & & \mathrm{C} 2 \mathrm{(OH})\end{array}$


Hamilton, K.O., Yazdanian, M., and Audus, K.L. (2001) Modulation of P-glycoprotein activity in Calu-3 cells using steroids and bligands. Int. J. Pharm. 228, 171-179. PMID: 11576779. Publisher's official version: <http://dx.doi.org/10.1016/S03785173(01)00836-5> . Open Access version: $\underline{\text { http://kuscholarworks.ku.edu/dspace/. }}$

\section{Figure 2.}

(a)

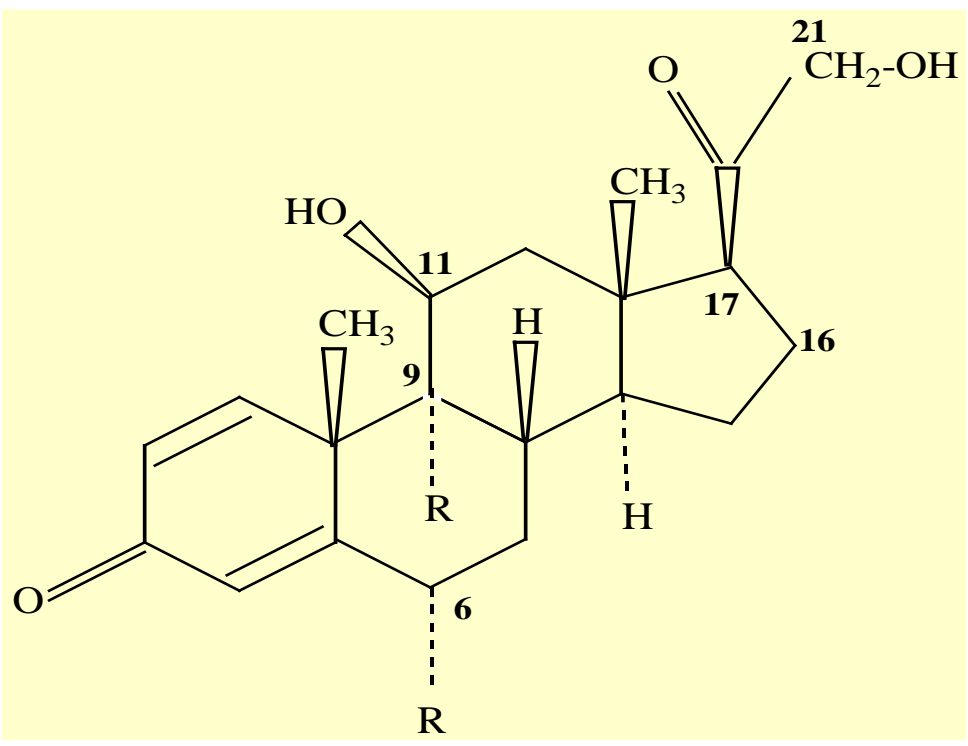

(b)

\begin{tabular}{|c|c|c|c|}
\hline Steroid & $\underline{6}$ & $\underline{9}$ & 16,17 \\
\hline Dexamethasone* & $\mathrm{H}$ & $\mathrm{F}$ & $\mathrm{OH}, \mathrm{CH}_{3}$ \\
\hline Beclomethasone & $\mathrm{H}$ & $\mathrm{Cl}$ & $\mathrm{OH}, \mathrm{CH}_{3}$ \\
\hline Budenoside & $\mathrm{H}$ & $\mathrm{H}$ & butylidenebis(oxy) \\
\hline Flunisolide & $\mathrm{F}$ & $\mathbf{H}$ & 1-methylethylidenebis(oxy) \\
\hline Triamcinolone & $\mathrm{H}$ & $\mathrm{F}$ & $\mathrm{OH}, \mathrm{OH}$ \\
\hline
\end{tabular}


Hamilton, K.O., Yazdanian, M., and Audus, K.L. (2001) Modulation of P-glycoprotein activity in Calu-3 cells using steroids and bligands. Int. J. Pharm. 228, 171-179. PMID: 11576779. Publisher's official version: <http://dx.doi.org/10.1016/S03785173(01)00836-5> . Open Access version: http://kuscholarworks.ku.edu/dspace/.

\section{Figure 3.}<smiles>CCCC(=O)Nc1ccc(OCC(O)CNC(C)C)c(C(C)=O)c1</smiles><smiles>CC(C)(C)NCC(O)COc1cccc2c1C[C@H](O)[C@H](O)C2</smiles><smiles>CC(C)(C)NCC(O)c1ccc(O)c(CO)c1</smiles><smiles>CC(C)NCC(O)COc1cccc2ccccc12</smiles><smiles></smiles><smiles>CC(C)(C)NCC(O)COc1nsnc1N1CCOCC1</smiles> 
Hamilton, K.O., Yazdanian, M., and Audus, K.L. (2001) Modulation of P-glycoprotein activity in Calu-3 cells using steroids and bligands. Int. J. Pharm. 228, 171-179. PMID: 11576779. Publisher's official version: <http://dx.doi.org/10.1016/S0378-

5173(01)00836-5> . Open Access version: $\underline{\text { http://kuscholarworks.ku.edu/dspace/. }}$

\section{Figure 4.}

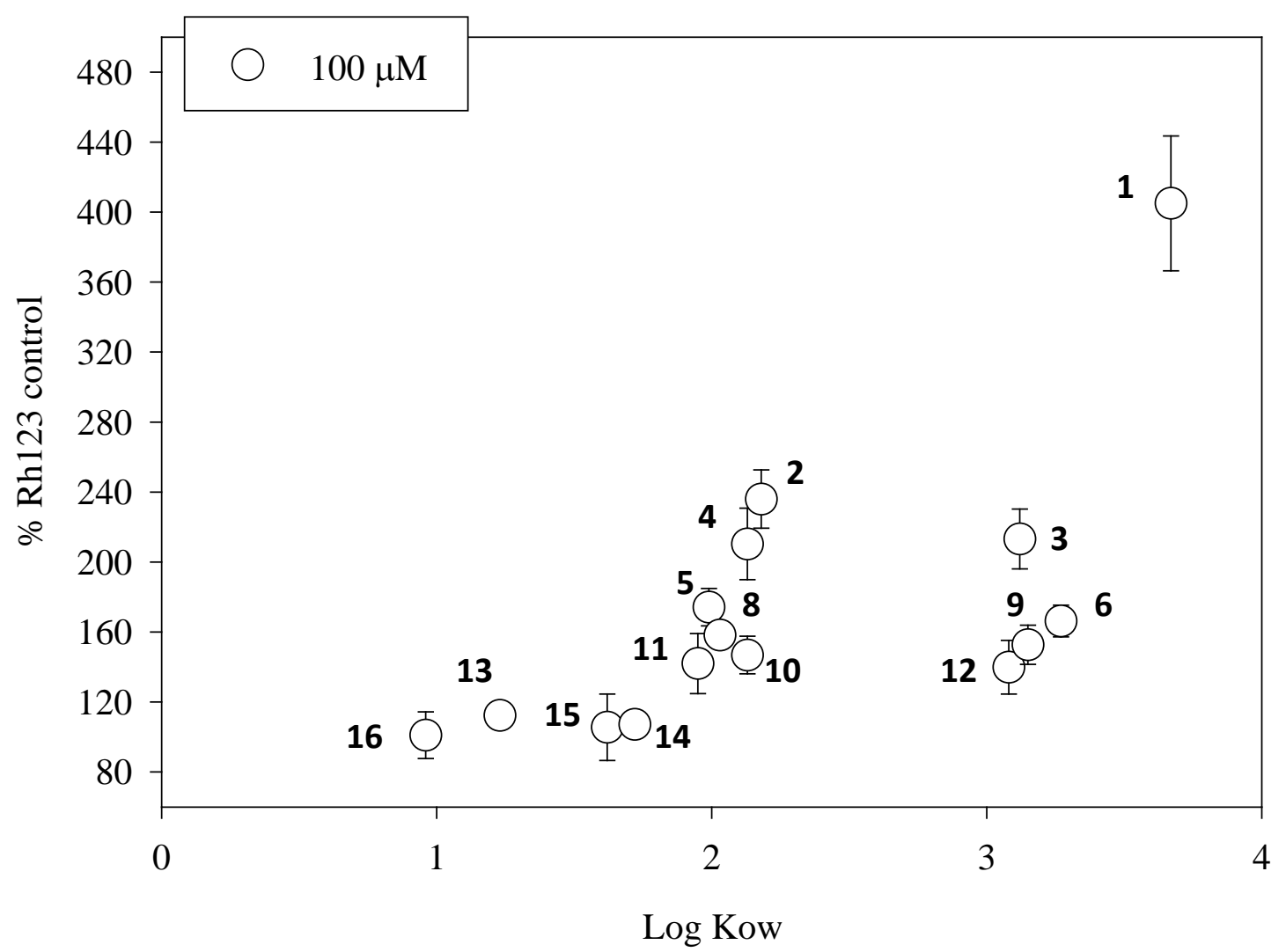


Hamilton, K.O., Yazdanian, M., and Audus, K.L. (2001) Modulation of P-glycoprotein activity in Calu-3 cells using steroids and bligands. Int. J. Pharm. 228, 171-179. PMID: 11576779. Publisher's official version: <http://dx.doi.org/10.1016/S03785173(01)00836-5> . Open Access version: http://kuscholarworks.ku.edu/dspace/.

\section{Figure 5.}

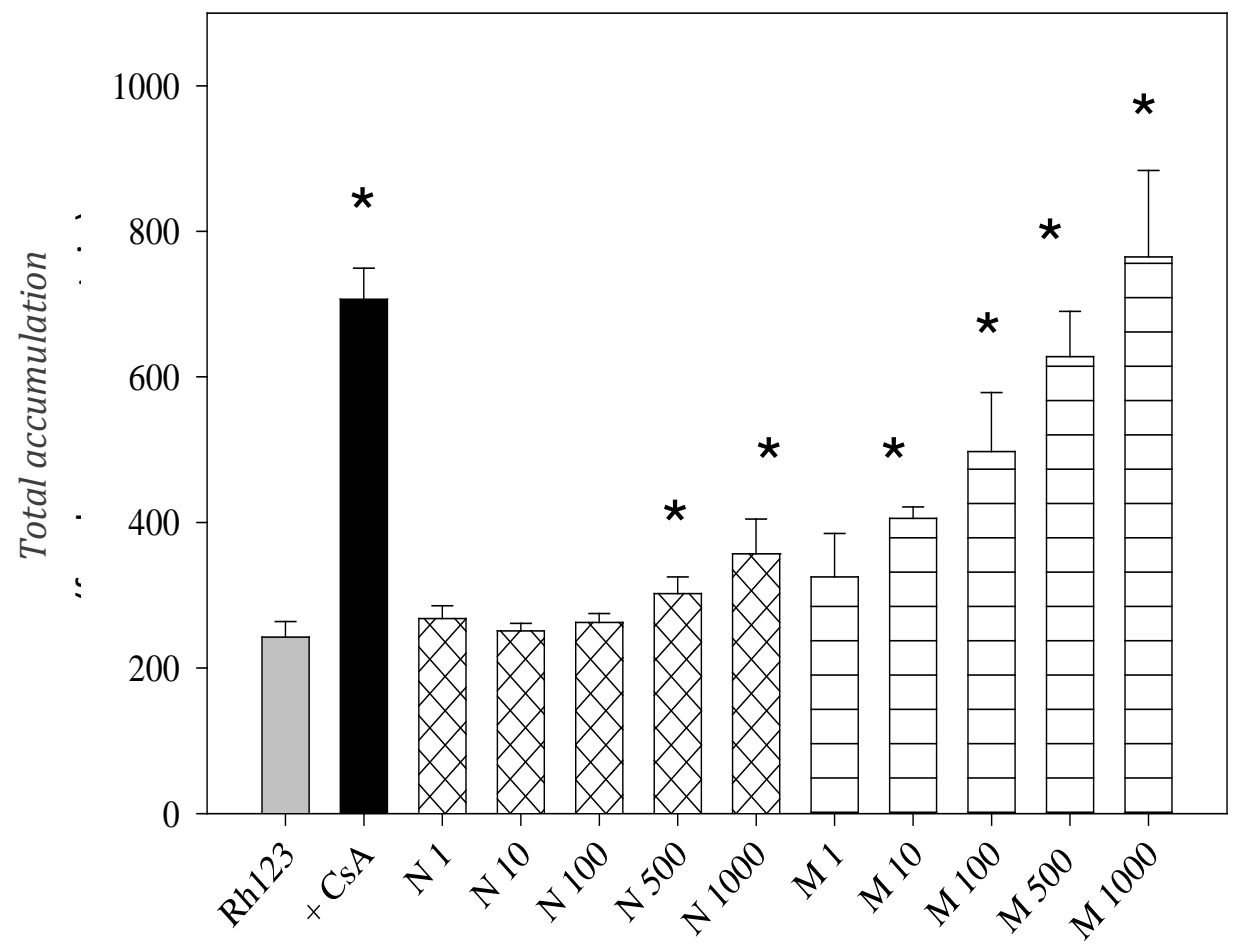


Hamilton, K.O., Yazdanian, M., and Audus, K.L. (2001) Modulation of P-glycoprotein activity in Calu-3 cells using steroids and bligands. Int. J. Pharm. 228, 171-179. PMID: 11576779. Publisher's official version: <http://dx.doi.org/10.1016/S03785173(01)00836-5> . Open Access version: http://kuscholarworks.ku.edu/dspace/.

Figure 6.

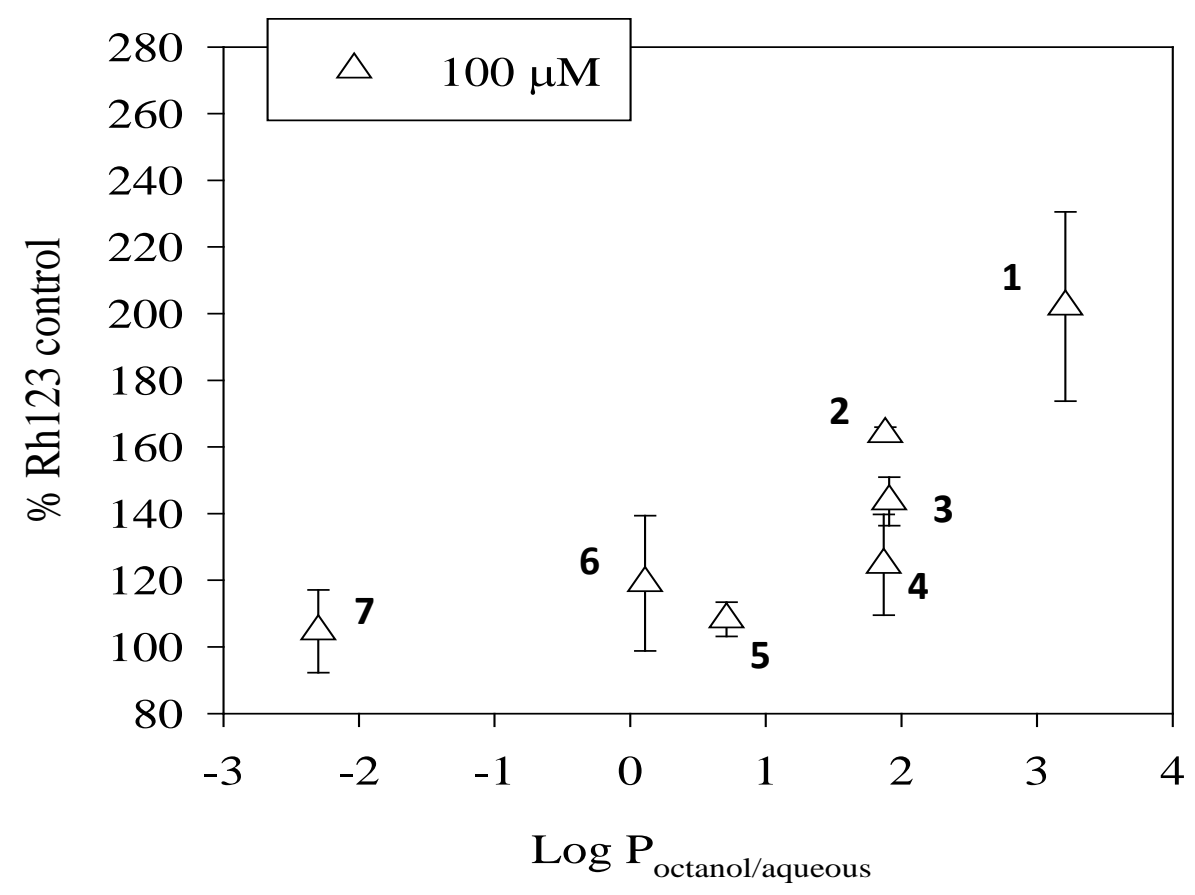

